Pamiętnik Literacki 2012, 1, s. 77-85
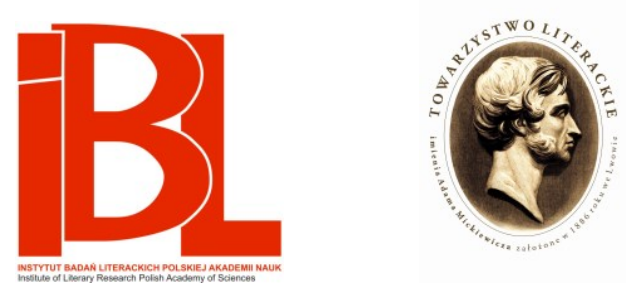

\title{
O naturze duszy. Witkacy czyta „Emancypantki” Bolesława Prusa
}

Wojciech Sztaba 


\section{O NATURZE DUSZY \\ WITKACY CZYTA „EMANCYPANTKI” BOLESŁAWA PRUSA}

Bolesław Prus zamieścił w czterech rozdziałach Emancypantek mały wykład filozoficzny profesora Dębickiego udzielony dwojgu słuchaczom, Madzi i Zdzisławowi Brzeskim ${ }^{1}$. Powieść, drukowana w latach 1890-1893 w „Kurierze Codziennym", ukazała się w formie książkowej w 1894 roku. Jej egzemplarz znajdował się z pewnością w domowej bibliotece Witkiewiczów. Stanisław Witkiewicz przyjaźnił się z Prusem od czasów współpracy w redakcji „Wędrowca”, łączyły ich poglądy społeczne i artystyczne, Prus cenił wysoko twórczość malarską Witkiewicza ${ }^{2}$. Witkacy mógł czytać Emancypantki około roku 1900, kiedy pracował nad pierwszym projektem filozoficznego systemu opisania oraz pojmowania świata i przerabiał liczne lektury filozoficzne z Kantem i Schopenhauerem na czele ${ }^{3}$.

Wykład prof. Dębickiego mógł zaciekawić Witkacego z dwóch względów: przez tematykę dyskursu, tak bliską jego zainteresowaniom wyrażonym już w młodzieńczych próbach filozoficznych, oraz z powodu umieszczenia przez Prusa obszernych rozważań filozoficznych $\mathrm{w}$ ramach gatunku popularnej powieści. Tę strategię uprawiania filozofii rozwinie Witkacy później we własnej twórczości,

1 O wykładzie Dębickiego pisał L. W ł o d e k w opublikowanej 6 lat po śmierci autora Emancypantek książce Bolesław Prus. Zarys społeczno-literacki (Warszawa 1918, s. 277-289), a ostatnio J. To m k o w s k i w rozdziale Lekcja profesora Dębickiego swojej pracy Mój pozytywizm (Warszawa 1993, s. 343, passim).

2 S. Witkiewicz i B. Prus znali się od r. 1885, kiedy obaj współpracowali w „Wędrowcu”. Ich ścisłe kontakty osobiste i artystyczne przedstawił Z. P i a s e c k i w książce Stanisław Witkiewicz. Młodość $i$ wczesny dorobek artysty (Warszawa-Wrocław 1983, s. 233, passim). Jak czytamy u W ł o dk a (op. cit., s. 100): „W głośnym swego czasu sporze Witkiewicza z malarzami monachijskimi Prus staje wyraźnie po jego stronie, ceniąc w nim człowieka, który "pisze i maluje to, co gruntownie rozumie i głęboko odczuwa, a całe jego życie jest ilustracją tej smutnej prawdy, że u nas nie popłaca wielki umysł i wielkie serce, ale głośna reklama i stosunki«. Przy tym »każde dzieło Witkiewicza jest niby oknem, otwartym na widok prosty, spoza którego przegląda wzniosłość. Witkiewicz, jako pejzażysta, robi wrażenie - nie malarza, który chodzi po świecie z farbami, płótnem, dużym parasolem i - maluje, ale człowieka, który spokojnym, prawie cichym głosem opowiada swoim przyjaciołom rzeczy nadzwyczajne, jakie wypatrzy w naturze «".

3 Ślad tej lektury odnaleźć można w wydanej w 1927 r. powieści S. I. W it k i e w i c z a Pożegnanie jesieni, gdzie Atanazy w przygrywce do erotycznej akcji z Helą Bertz wspomina słowa Norskiego z Emancypantek: „A każda bestyjka inna” (cyt. z wyd. w oprac. A. M i c iń s ki ej: Warszawa 1992, s. 29. Dzieła zebrane. [T. 2]). 
w powieściach i dramatach. Zgodnie zresztą ze swoją teorią nie uznawał on powieści za sztukę - z powodu jej zbyt mocnego związku z „treściami życiowymi”. Ale właśnie dzięki tym związkom filozofia w literackiej oprawie ukazuje swój niespekulatywny, życiowy charakter. Wyraźnym przesłaniem powieściowego wykładu w Emancypantkach jest to, że egzystencjalny niepokój stanowi źródło filozofii. I o tym Witkacy będzie ustawicznie przypominał, szukając sposobu na życie z Tajemnicą Istnienia w tle. Stąd tak często podkreślał znaczenie „poglądu życiowego" dla rozważań filozoficznych.

Prof. Dębicki prowadzi wykład przez parę kolejnych dni, zaczyna od pytania egzystencjalnego o sens życia w obliczu śmierci. Zwraca się do młodego, śmiertelnie chorego mężczyzny, przerażonego i nie znajdującego rady ani pocieszenia w swym materialistycznym światopoglądzie. Filozofia spełnia tu zadanie karetki pogotowia: jej działanie musi być szybkie, zdecydowane i skuteczne, bo ratuje, jeśli już nie życie, to duszę. I taki też jest wykład, w którym nie ma czasu na długie spekulacje; im prostsza, jaśniejsza jest myśl, tym większa szansa, że szybko dotrze do potrzebującego pomocy. Co się po części udaje - pacjent, mimo że na końcu umiera, to jednak (jak sugeruje powieść) bez strachu, rozumiejąc świat i siebie.

Wykład dotyczy spraw ostatecznych - Boga, nauki i świadomości, a także materializmu, fizyki, biologii, sceptycyzmu i nieśmiertelności duszy - więc tematów, które znajdowały się tak wtedy, jak i później w centrum zainteresowań Witkiewicza. Dębicki, zaznaczmy od razu, na pytanie o sens życia odpowiada w duchu na wskroś religijnym, a proponowanym przez niego rozwiązaniem jest nieśmiertelność duszy. Aby jej dowieść, zaczyna od wykładu o istnieniu człowieka, jego konstytucji, świadomości, o poczuciu ,ja”. Czujący podmiot zajmuje szczególne miejsce w przedstawieniu sensu istnienia - od niego zaczyna się wszelka filozofia. Wykład staje się przeglądem stanowisk w dyskusji nad budową świata i naturą poznania: czy odkrycia nauki, posługującej się niewyobrażalnymi dla ludzkiego umysłu wymiarami, potrafią wyjaśnić świat? Jak podmiot - poznająca świadomość - postrzega rzeczywistość i jakie są granice poznania? W wykładzie raz po raz padają nazwiska reprezentantów tego wielkiego dyskursu: Hippolyte Taine, Jakob Moleschott, Herbert Spencer, Carl Vogt, Gustave-Adolphe Hirn, James Prescott Joule, Oscar Emil Meyer, William Thomson, Charles Babbage.

Długi czas uważano, iż pod nazwiskiem prof. Dębickiego ukrywa się prawdziwa postać: Władysław Michał Dębicki (1853-1911)4, ksiądz i filozof, autor takich prac, jak Wielkie bankructwo umystowe czy Filozofia nicości. Na tezach zawartych w jego książce Nieśmiertelność człowieka jako postulat filozoficzny przyrodoznawstwa oprzeć miał swój wywód powieściowy profesor. Więc w czasach,

4 Twierdzenie o pierwowzorze postaci Dębickiego znaleźć można w monografii Wło d ka (op. cit., s. 277-289). Autor dowodzi, że tezy powieściowego profesora Prus przejął z pracy księdza Dębickiego: „Zaczerpnął ją Prus przeważnie ze studium Władysława Michała Dębickiego Nieśmiertelność czlowieka jako postulat filozoficzny przyrodoznawstwa (Warszawa 1891, wyd. 5), dając rzadki dowód sumienności w nazwisku profesora z Emancypantek, któremu wkłada w usta tę teorię, takim samym jak filozofa, z którego pracy korzystał" (ibidem, s. 278). Natomiast To m k o w s k i (op. cit., s. 205, przypis 17) uważa za E. P i és c i k ow s k i m, autorem monografii Bolesława Prusa „Emancypantki” (Warszawa 1970), że postać profesora z powieści nie jest wzorowana na księdzu Dębickim. 
gdy Witkacy czytał powieść Prusa, łączono postać księdza-filozofa z filozofem powieściowym ${ }^{5}$.

W Wielkim bankructwie umysłowym ${ }^{6}$ Dębicki, myśliciel ultrakonserwatywny, rozprawia się z filozofią sceptycyzmu, skrajnego idealizmu, solipsyzmu i nihilizmu, potępia $\mathrm{z}$ dużą dozą demagogii właściwie całą istotną tradycję europejskiej filozofii, dla której: „,idea przyczyny zewnętrznej jest niczym więcej, tylko »moją« ideą"7, więc i myślicieli czytanych i cenionych przez młodego Witkiewicza - jak Kant, Schopenhauer czy Nietzsche. Mimo stronniczości i jadowitych komentarzy praca Dębickiego ma pewną zaletę: stanowi zwięzłe sprawozdanie $\mathrm{z}$ dysputy o istnieniu świata, od Kartezjusza do Taine'a, z bogatym zbiorem cytatów, które mimo negatywnego komentarza nie tracą nic na znaczeniu. Dzisiejszemu czytelnikowi pokazuje horyzont ówczesnych sporów filozoficznych, uaktualnia minione debaty, polaryzuje tematy, po części oddając atmosferę, w której Witkacy zabierał się do formułowania swojej filozofii. Dowiadujemy się, w jakim dyskursie brał udział młody Witkiewicz, w jakim stopniu ten dyskurs wpłynął na kierunek jego myślenia, dlaczego np. tak mocno zajmowała go sprawa uczucia, świadomości, świata zewnętrznego i wewnętrznego oraz obawa przed solipsyzmem - świadomością zamkniętą we własnym wyobrażeniu nie istniejącego realnie poza nią świata. Powieściowy, fikcyjny wykład w Emancypantkach o istnieniu świata, o Bogu i świadomości jest pars pro toto całej ważnej, może najważniejszej wtedy dyskusji o naturze świadomości i postrzegania - tej dyskusji, z której powstał jego system.

Już w pierwszych młodzieńczych wypracowaniach formułuje Witkacy podstawy swojego filozofowania - szuka początku myślenia, wytycza i mierzy obszar problemów wedle niego najistotniejszych, rozgląda się za odpowiednią metodą ${ }^{8}$. Nie są te teksty tylko sprawdzianem wiedzy, ale też pierwszym ustaleniem tego, czym w filozofii warto się zająć.

A więc przede wszystkim świadomością i jej warunkami:

Żeby powstała świadomość „Ja”, trzeba, żeby się na to złożyły dwie części: uczucie, coś bezpośredniego, czego nie możemy z niczym porównać, coś, co się nie da rozłożyć na czynni-

5 J. D e g l e r przypuszcza (e-mail z 4 XI 2010), że w późniejszym o ćwierć wieku Pożegnaniu jesieni Witkacy połączył obie postaci - powieściowego profesora i księdza-filozofa - w jednej osobie księdza Hieronima Wyprztyka. Mimo tonu ironii, groteski i karykatury odróżniającego powieść Witkacego od pozytywnego przesłania Prusa scena nawracania Heli Bertz ma wiele wspólnego z zamiarem prof. Dębickiego ratowania duszy Zdzisława Brzeskiego. Ksiądz Wyprztyk jest jednak w trudniejszej sytuacji, ponieważ jego uczennica to piekielnie niebezpieczna kusicielka, która na nowo odgrywa historię św. Antoniego, tym razem obierając jako cel księdza Hieronima. Argumenty Wyprztyka są w dużej mierze argumentami Witkiewicza, m.in. o bezpośrednio danej osobowości jako źródle religii i sztuki, a także jego jest krytyka Bergsona, logików, fizykalistów i psychologistów.

6 W. M. D ę b i c k i, Wielkie bankructwo umystowe. Rzecz o nowoczesnym skrajnym sceptycyzmie naukowo-filozoficznym. Z dodaniem studium: Koniec wieku XIX-go pod względem umystowym. Charakterystyka znamion szczególnych. Warszawa 1895. Książka znajdowała się w zbiorach Czytelni Zakopiańskiej obok innej pozycji W. M. D ę b i c k i e g o, Filozofia nicości, oraz wymienionej w Emancypantkach rozprawy H. Ta in e' a De l'inteligence.

7 W. M. D ę b i c k i, Wielkie bankructwo umysłowe, rozdz. 6. Cyt. ze strony: http://www.ultramontes.pl/wielkie_bankructwo_6.htm

8 S. I. W i t k i e w i c z, Pisma młodzieńcze 1902-1903: O dualizmie; Marzenia improduktywa. (Dywagacja metafizyczna). W: O idealizmie i realizmie. Pojęcia i twierdzenia implikowane przez pojęcie Istnienia i inne prace filozoficzne. Zebrał, oprac. i przypisami opatrzył $\mathrm{B}$. M i c hals k i. Warszawa 1977. Pisma filozoficzne i estetyczne. [T. 3]. 
ki pierwsze, bo samo jest już najpierwszym elementem, i następnie jego uświadomienie obiektywne ${ }^{9}$.

To, czym jest uczucie świadomości istnienia, czyli pojęcie „Ja”, należy wedle Witkiewicza do głównych pytań filozofii (i jest kolejnym punktem jego filozoficznego projektu). Bezpośredniość doświadczenia przechodzi w trakcie uświadamiania go sobie proces analizy, odczucie istnienia znika, zmienia się w pojęcia, przestaje być autentyczne. To pułapka, w którą wpadają nauki opierające się na badaniach analitycznych: ,Nauki ścisłe badają jedynie zjawiska. [...] w metodzie tych nauk leży zaprzeczenie ostatecznego ich celu" ${ }^{10}$, a jest nim poznanie rzeczywistości, objaśnienie bytu. Ale czy można inaczej, czy tajemnica nie pozostanie zawsze tajemnicą? Kompromisowe rozwiązanie znajduje Witkiewicz w metafizyce:

Jest ona sformułowaniem analitycznym tych rzadkich chwil umysłu ludzkiego, gdy oświetlony jakąś wewnętrzną błyskawicą, widzi całą otchłań nieznanego, które go otacza i które tkwi w nim samym ${ }^{11}$.

Metodą, dzięki której ten wyjątkowy proces myślenia da się ująć i opisać, jest wedle Witkacego obserwacja siebie samego:

Każdy człowiek jest dla siebie podmiotem i przedmiotem, [...] analizę wypada nam więc zacząć od nas samych. Po zanalizowaniu naszego „Ja” widać, że podstawą naszą są zawsze uczucia $[\ldots]^{12}$.

To przybliżone kontury Witkacowskiego projektu filozofowania w latach 1902-1903. Rozpoznaje się w nim późniejsze konkretyzacje i uzupełnienia - pojęcia uczuć metafizycznych, bezpośredniego odczucia jedności Istnienia Poszczególnego, czy introspekcji, która całej teorii - i filozofii, i estetyce - nadaje wyjątkowy charakter. Teoria Witkacego jest teorią introspektywną.

W wykładzie prof. Dębickiego w Emancypantkach znajduje się wiele tez, tematów i sformułowań, których echo odzywa się w tekstach Witkacego. Zacznijmy od pojęcia świadomości jako poczucia siebie od wewnątrz i związanej z tym pojęciem introspekcji.

Naturę duszy, czyli rozmaite jej zdolności i nieskończone łańcuchy duchowych zjawisk odkrył nam nie wzrok, nie skalpel, ale - wewnętrzna obserwacja, nas ze poczucie s a m y h s i e bi e. Więc to poczuci e jest właściwym zmysłem, jedynym zmysłem, którym b e z p ośr e d n i o możemy badać naszą duszę. [s. 439] ${ }^{13}$

Czuję kolor czerwony i zielony, tony wysokie i niskie, czuję twardość i miękkość, ciepło i zimno; czuję zapach octu i róży, głód i trudność w oddychaniu, ruchy moich rąk i nóg. Czuję radość i smutek, miłość i nienawiść, czuję, że czegoś pragnę, a czegoś lękam się, że pamiętam przeszłość. Czuję wreszcie, że jedne z moich kombinacyj umysłowych odpowiadają faktom spostrzeżonym przez zmysły, a inne kombinacje są - moimi własnymi utworami.

Słowem - odkrywam cały świat zjawisk będących tylko rozmaitymi formami czucia, tego dziwnego czucia, które czuje nawet - samo siebie. A jednocześnie spostrzegam, że ani fizyka, ani chemia, ani teoria komórek, ani wszystkie razem wzięte doświadczenia fizjologiczne nie

\author{
9 Ibidem, s. 16. \\ 10 Ibidem, s. 21. \\ 11 Ibidem, s. 22. \\ 12 Ibidem, s. 28. \\ 13 W ten sposób lokalizuję cytaty z Emancypantek B. P r u s a (t. 2. Warszawa 1986).
}


powiedzą mi: c zy m je st c z u c i e? Jest to bowiem fakt elementarny i dla każdego człowieka jedyny.

Wiem, [...] że czucie, które ja posiadam i którym ogarniam cały świat, że to moje czucie jest jedyne w naturze. Ja za nikogo czuć nie mogę i nikt za mnie; ja nikomu nie zajrzę w głąb jego czucia i nikt nie zajrzy w moje. Pod tym względem jestem istotą wyłączną i niezastąpioną. [s. 440]

M oj e c z u c i e, które każdy z nas posiada, jest faktem elementarnym. [s. 448]

W naszym czuciu istnieją nie tylko zwierciadła do odbijania realnych zjawisk natury, ale istnieją także szufladki, w których wyrabiają się pojęcia niekiedy wręcz sprzeczne z doświadczeniem. My na przykład nie widzieliśmy wystygłego słońca, rozbitej ziemi, a choćby naszego własnego ciała w postaci rozkładających się zwłok. A jednak o wszystkich tych rzeczach możemy myśleć... [s. 449-450]

Dlaczegóż więc dedukcje w dziedzinie psychologii mają nie być pewnymi?... Wszak opierają się na c z u c i u, a czucie jest większym pewnikiem aniżeli jakikolwiek inny fakt na świecie czy w nauce. [s. 453]

\section{Przypomnijmy, jak sformułował to Witkacy:}

Żeby powstała świadomość „Ja” trzeba, żeby się na to złożyły dwie części: uczucie, coś bezpośredniego, czego nie możemy z niczym porównać, coś, co się nie da rozłożyć na czynniki pierwsze, bo samo jest już najpierwszym, i następnie jego uświadomienie obiektywne.

Witkacy idzie tu już o krok dalej niż powieściowy profesor, wprowadza obserwatora, który dokonuje introspekcji, analizuje ją i w tym momencie doświadcza sam na sobie podwójnej perspektywy, owego dualizmu „Ja” objawiającego się w oscylacji między bezpośrednim uczuciem a jego uświadomieniem. To odczucie siebie w sobie i siebie wobec świata nazwie w późniejszych pracach odczuciem bezpośrednim Istnienia Poszczególnego i będzie starał się precyzyjnie omówić ów złożony, zawsze bliski aporii stan rzeczy, łączący w jednym momencie odczuwanie, myślenie i pamiętanie. Opis tego stanu uważał za jedno z głównych zadań filozofii, dostępne, jak mówi też prof. Dębicki, w introspekcji.

Wśród odczuć, które konstytuują pierwotną, fundamentalną świadomość „Ja”, wyodrębni później Witkacy odczucie metafizyczne. Nie ma tego pojęcia w pierwszych tekstach, choć wiele w nich mowy o metafizyce jako sposobie opisania bytu. To istotna podmiana znaczeń: „metafizyczność” przestanie być abstrakcyjną spekulacją i zwiąże się z „realnym” odczuwaniem, wracając do „czucia” siebie, tak jak to rozumiał prof. Dębicki.

Także problem „Ja i nie-Ja”, tak jak przedstawiony jest w powieści, pojawi się dopiero później, w monadologicznym systemie Witkacego. W Emancypantkach ukazany jest ów system następująco:

A teraz wyobraź pan sobie kulę czy sześcian, czy inną bryłę zbudowaną z substancji czującej i ciągłej. Gdyby na bryłę tę nic nie działało, wewnątrz jej odbywałyby się jakieś jednostajne ruchy, a jej czucie miałoby formę półsenną. W chwili jednak, gdyby bryła ta uległa dotknięciu, gdyby uderzył o nią dźwięk, promień ciepła lub światła, w masie jej powstałby nowy ruch i czucie. Ten punkt, na który działałby wpływ zewnętrzny, doznałby wrażenia, a reszta masy poczułaby, że w niej zaszła jakaś zmiana, i powiedziałaby w sobie: ,ja czuję wrażenie", jeżeli wolno użyć podobnego porównania.

Słowem: w masie jednolitej, posiadającej zdolność czucia, każda pobudka zewnętrzna wywołałaby dwa zjawiska. Jednym byłby ruch pochodzący z zewnątrz, któremu odpowiadałoby czucie zewnętrzności; drugim byłoby starcie nowego ruchu z ruchem już istniejącym, któremu odpowiadałoby poczucie własnej masy, czyli swojego j a. [s. 455] 
Czucia wewnętrzne i zewnętrzne, granica między postrzeganiem siebie a postrzeganiem świata będzie również stałym tematem przewijającym się u Witkacego. W wykładzie prof. Dębickiego znaleźć można nawet zasadę Jedności w Wielości, może bliskiej myślom Leibniza, której Witkacy jeszcze nie sformułował w młodzieńczych tekstach:

to, co nazywamy naturą, składa się z mnóstwa przedmiotów oddzielnych. Są oddzielne drzewa, oddzielne krowy, oddzielne muchy, oddzielne ziarnka piasku, oddzielni ludzie, oddzielne promienie światła $\mathrm{i}$ oddzielne zmiany, jakim ulegają te promienie. Tymczasem $\mathrm{w}$ duszy naszej istnieje tak potężny popęd do jedności, że tę jedność narzucamy naturze i mówimy: las, stado, rój, ława piaszczysta, społeczeństwo, optyka. Wszystkie teorie naukowe i wszystkie dzieła sztuki, wszystkie prace ludzkie i wyroby techniczne powstały stąd, że dusza nasza narzuca swoją jedność nieskończonej rozmaitości, jaka istnieje w naturze.

Prawda, że są przedmioty na pozór jednolite, na przykład: stół, woda, ściana... Ale ta jednolitość opiera się na niedokładności zmysłów; w gruncie rzeczy bowiem stół, woda i ściana składają się z cząstek, a te cząstki z oddzielnych i nie przylegających do siebie atomów.

Krótko mówiąc: dusza nasza jest tak jednolitą, że z największą siłą narzuca swoją jednolitość wszystkiemu. I dopiero wówczas uznaje rozmaitość, gdy ją do tego gwałtem zmuszą zmysły, w każdej chwili przeszkadzając jej do utworzenia jedności. [s. 450-451]

W dalszym ciągu tego wywodu pojawia się zdanie, które przywodzi na myśl kontrowersyjny hylozoizm Witkiewicza (Tadeusz Kotarbiński pisząc o tej koncepcji w systemie filozoficznym Witkiewicza skomentował jej znaczenie nie bez złośliwości: ,zegarek składa się z żyjątek” ${ }^{14}$ ).

Przypuśćmy jednak (co nie jest rzeczą niemożliwą), że atomy posiadają czucie, a nawet świadomość $[\ldots]$.

Stąd w naturze widzimy bezładną materię kosmiczną, potem określone pierwiastki chemiczne, potem związki chemiczne, dalej - kryształy, komórki i niższe organizmy. Wszystko to są indywidualności półświadome, które w stopniowym rozwoju dosięgają zupełnej świadomości, coraz wyższej, coraz zdolniejszej do poznania Boga. [s. 451-452, 463]

I jeszcze inna myśl prof. Dębickiego, w której zwraca uwagę to, że teoria Czystej Formy ustalając analogię między dziełem sztuki a Jednością w Wielości całego bytu zawiera ziarnko pradawnej analogii hermetycznej dotyczącej odpowiedniości między makro- i mikrokosmosem, twierdzącej, że to, co na dole, jest takie jak to, co w górze, a to, co na górze, jest takie jak to, co w dole:

Dusza nasza jest małym wszechświatem, małym zegarkiem wśród olbrzymiego zegara. I tylko dlatego odczuwamy zjawiska natury, pojmujemy je i odgadujemy; tylko dlatego nasz rozwój indywidualny podobny jest do rozwoju, a nasza twórczość do twórczości całej natury. [s. 462]

Dużą część wykładu prof. Dębickiego stanowi krytyka stanowiska nauk ścisłych: materializmu i opartej na nim psychologii. Podobną krytykę wyraża również młody Witkiewicz: „Nauki ścisłe badają jedynie zjawiska. [...] w metodzie tych nauk leży zaprzeczenie ostatecznego ich celu". Ale w późniejszych pracach nie

14 T. K o t a r b iń s k i, Filozofia St. I. Witkiewicza. W zb.: Stanisław Ignacy Witkiewicz. Człowiek i twórca. Księga pamiątkowa. Red. T. Kotarbiński, J. E. Płomieński. Warszawa 1957, s. 15. Zob. też B. M i c h als k i, Jeszcze raz o znaczeniu filozofii w twórczości Stanisława Ignacego Witkiewicza. W zb.: Witkacy w Polsce i na świecie. Red. M. Skwara. Szczecin 2001, s. 127. 
poprzestanie na krytyce fizykalizmu i psychologizmu, spróbuje ich pogodzenia, wykorzystania do opisania stanu rzeczy. Zauważmy, że i prof. Dębicki w matematyce i fizyce szuka potwierdzenia istnienia duszy:

Dusza zaś należy tymczasem do zakresu metafizyki, chociaż, moim zdaniem, do takiej samej metafizyki należy cała dzisiejsza fizyka matematyczna z jej atomami, teorią gazów i optyką.

W chwili gdy mówimy, że atom ma wielkość dwumilionowej części milimetra, że cząstka wodoru w ciągu sekundy uderza się dziewięć miliardów razy o cząstki sąsiednie, że światło czerwone polega na trzystu osiemdziesięciu siedmiu trylionach drgań na sekundę, w tej chwili opuszczamy dziedzinę eksperymentu i przenosimy się na ocean metafizyki. [s. 454]

O czym dotąd nie było mowy - to o religijnym czy spirytualistycznym tle wywodów prof. Dębickiego. Bo nie tylko przekonuje on o nieśmiertelności duszy i przytacza na to dowody, ale także wyjaśnia jej „budowę”, powołując się na popularną w tych czasach teorię na temat eteru jako substancji, w której „zawierają się" zarówno wszechświat, jak i dusza.

Stanowisko Witkacego wobec religii wydaje się warte rozpatrzenia. Jaka byłaby jego odpowiedź na pytanie Małgorzaty postawione Faustowi: ,jak to jest naprawdę z twoją religią?" W ramach swojego systemu Witkacy nie odpowiada wprost, religia jest zjawiskiem, które umieszcza w triadzie ze sztuką i filozofią, na różne sposoby mierzących się z Wieczną Tajemnicą; religia to sposób łagodzenia, usuwania grozy, strachu przed bytem - i niebytem.

W Marzeniach improduktywa znajduje się rozdział O osobowym Bogu, wyjaśniający, „na czym polegają niekonsekwencje wszelkiego teizmu”. Witkacy pisał: „Jedyną możliwą religią jest panteizm, który jest symbolem jedynej rzeczywiście niedogmatycznej dualistycznej metafizyki" " ${ }^{15}$. Tekst Witkacego to rodzaj polemiki z poglądami głoszonymi także w powieści Prusa, można słyszeć w nim niemal odpowiedź na postawę prof. Dębickiego, który przyjmuje istnienie osobowego Boga i stanowczo odrzuca panteizm:

ta bezmierna Moc wcale nas nie przeraża: myślimy o Niej bez trwogi, z ufnością i nadzieją, jak dzieci o ojcu. [s. 468]

Prus zajmował się zjawiskami paranaturalnymi, od nauki oczekując ich wythumaczenia. Brał udział, zachowując krytyczny dystans, w seansach spirytystycznych, jak np. ze słynnym medium Eusapią Palladino, czy w spotkaniach organizowanych przez swego przyjaciela Juliana Ochorowicza (pierwowzoru postaci Ochockiego z Lalki). Zainteresowanie Witkacego mediumizmem może mieć swój początek już w tym czasie, w atmosferze ciekawości wobec nieznanego, do której przyczynił się niemało także autorytet Prusa - pisarza i publicysty ${ }^{16}$.

Jeżeli przed XIX-ma wiekami Chrystus wypędza duchy z opętanych, to dlaczego dziś, po XIX-tu wiekach, nie mamy prawa choćby tylko - mówić o istnieniu duchów? I - pytam się - co straci ludzkość, jeśli uwierzy, iż poza tym światem materialnym i widzialnym istnieje inny, niewidzialny, nie mniej jednak rzeczywisty? ${ }^{17}$

${ }_{15}$ W i t k i e w i c z, Pisma młodzieńcze 1902-1903, s. 21.

16 Zob. Włod e k, op. cit., s. 289-296. - To m k o w s k i, op. cit., s. 223, passim.

17 Tekst B. Pru s a cyt. za: Włode k, op. cit., s. 290. 
I w Emancypantkach znaleźć można, w filozofii prof. Dębickiego, ślady tych zainteresowań ${ }^{18}$, a także wzmianki o metafizyce w zjawiskach badanych przez fizykę i matematykę, np. w nieskończenie małych lub wielkich wymiarach świata (zasada Wielkich Liczb, często przez Witkiewicza przywoływana dla opisania zjawisk wykraczających poza możliwość bezpośredniego poznania w granicach ludzkiego doświadczenia).

Według Dębickiego odpowiedzią na zagadkę tego innego, niewidzialnego świata jest zjawisko eteru, w nim dostrzegał „kładkę, która mogłaby połączyć fizykę z psychologią i - z powszechną wiarą ludzi w nieśmiertelność duszy” (s. 456). Profesor mówił: „według mojej hipotezy eter czujący jest substancją duchową, materiałem, z którego powstają dusze i który sam dąży do świadomości” (s. 467).

Witkacy nie będzie wprawdzie eteru łączył z odpowiedzią na pytanie o nieśmiertelność ${ }^{19}$, ale problem, w jaki sposób powiązać fizykę z psychologizmem, stanie się jednym z powtarzających się motywów jego filozofii.

Niniejsze przypomnienie wykładu prof. Dębickiego w powiązaniu z wczesnymi tekstami filozoficznymi Witkacego nie ma na celu sugerowania, że swój system Ontologii Ogólnej obmyślił on na podstawie lektury Emancypantek. To zwłaszcza dzieła filozoficzne kształtowały jego poglądy, dostarczały materiału do porównań, inspiracji i polemik. Zestawienie tekstu Prusa z ówczesnymi koncepcjami Witkacego daje głównie możliwość wejrzenia w proces powstawania systemu, pokazuje jego potencjalne koordynaty, pozwala obserwować ruch myśli, przesuwanie się akcentów, zamienianie się pojęć miejscami w systemie - i to wszystko, co ważne, w ramach emocjonalnego, sugestywnego obrazu literackiego. W powieści bowiem dyskurs naukowy znajduje może i uproszczoną, lecz wyraźniejszą formę, pomagającą zobaczyć jego sens nie tyle inaczej, co z łatwiej dostrzegalnymi konturami. Mówią o tym i powieści, i dramaty Witkacego.

Listopad 2010 - lipiec 2011

Dziękuję Januszowi Deglerowi i Janowi Gondowiczowi za uwagi dotyczące tekstu.

\section{Abstract}

WOJCIECH SZTABA

(Herrenberg)

ON THE NATURE OF SOUL.

WITKACY'S READING BOLESŁAW PRUS' "EMANCIPATIONISTS"

Bolesław Prus in his novel Emancipationists (Emancypantki) placed a philosophical lecture on the sense of existence. One of his protagonists, professor Dębicki, searching for evidence for the existence of soul, discusses the various views of contemporary sciences and philosophy and against

18 Zob. Tom kow s ki, op. cit., s. 205-210.

19 Późniejszy komentarz S. I. W i t k i e w i c z a do rozważań Dębickiego o eterze znajdziemy w jego dramacie Janulka, córka Fizdejki (w: Dramaty 3. Oprac. J. D e g 1 e r. Warszawa 2004, s. 124. Dzieła zebrane. [T. 7]): „W zmarzniętym na kamień wszecheterze od wieczności wymarłego Istnienia. Dosyć, bo pęknę!" 
such a background he suggests his own system of ideas in mathematics and physics based on a combination of science and religion.

Stanisław Ignacy Witkiewicz read the novel written by his father's friend in his youth, and in his philosophical and literary papers he adopted a number of subjects from Dębicki's lecture, especially the problem of "I - not I" expressed through introspection, the issue of the borderline between perception of oneself and perception of the world, and internal and external sensations. The lecture might have attracted Witkacy's interest also due to thorough philosophical considerations within the framework of the popular novel. He expanded such a strategy of developing philosophy also outside purely scientific field, namely in his own novels and dramas. 